\title{
Extrafloral nectaries in the genus Macaranga (Euphorbiaceae) in Malaysia: comparative studies of their possible significance as predispositions for myrmecophytism
}

\author{
BRIGITTE FIALA
}

Zoologie III, Röntgenring, 10, 8700 Würzburg, Federal Republic of Germany

AND

\section{ULRICH MASCHWITZ}

Zoologisches Institut, 7.W.-Goethe Universität, Siesmayerstr. 70, D-6000 Frankfurt, Federal Republic of Germany

Received 5 July 1990, accepted for publication 27 July 1990

Some species of the paleotropical tree genus Macaranga (Euphorbiaceae) live in close association with ants. The genus comprises the full range of species from those not regularly inhabited by ants to obligate myrmecophytes. In Malaysia (Peninsular and Borneo) 23 of the 52 species are known to be ant-associated $(44 \%)$. The simplest structural adaptation of plants to attract ants are extrafloral nectaries. We studied the distribution of extraftoral nectaries in the genus Macaranga to assess the significance of this character as a possible predisposition for the evolution of obligate myrmecophytism. All species have marginal glands on the leaves. However, only the glands of nonmyrmecophytic species function as nectaries, whereas liquids secreted by these glands in myrmecophytic species did not contain sugar. Some non-myrmecophytic Macaranga and transitional Macaranga species in addition have extrafloral nectaries on the leaf blade near the petiole insertion. All obligatorily myrmecophytic Macaranga species, however, lack additional glands on the lamina. The non-myrmecophytic species are visited by a variety of different ant species, whereas myrmecophytic Macaranga are associated only with one specific ant-partner. Since these ants keep scale insects in the hollow stems, reduction of nectary production in ant-inhabited Macaranga seems to be biologically significant. We interpret this as a means of (a) saving the assimilates and (b) stabilization of maintenance of the association's specificity. Competition with other ant species for food rewards is avoided and thereby danger of weakening the protective function of the obligate antpartner for the plant is reduced.

A comparison with other euphorb species living in the same habitats as Macaranga showed that in genera in which extrafloral nectaries are widespread, no myrmecophytes have evolved. Possession of extrafloral nectaries does not appear to be essential for the development of symbiotic ant-plant interactions. Other predispositions such as nesting space might have played a more important role.

KEY WORDS:-Macaranga - extrafloral nectaries - ant-plant interactions - evolution of myrmecophytism - Malaysia. 


\begin{tabular}{|c|c|c|c|c|c|c|c|c|c|c|c|c|}
\hline Introduction . . . & & & $v^{*}$ & - & & . & & & . & & & 288 \\
\hline Material and methods. & & & . & . & . & . & . & & . & & & 289 \\
\hline Results . . . . & & . & . & . & . & . & . & & . & & & 290 \\
\hline Glands on the leaf & $\arg$ & & . & . & . & . & . & & . & & & 290 \\
\hline Glands on the leaf & $\mathrm{ad}$ & . & . & . & . & . & . & & . & & & 290 \\
\hline Contents of secretic & & . & & . & . & . & . & & . & & & 296 \\
\hline Comparison with o & & up & & acea & & We & & & ysia & & & 298 \\
\hline Discussion . . & & . & . & . & . & . & . & & . & & & 300 \\
\hline Acknowledgements & & . & . & . & . & . & & & . & & & 304 \\
\hline References . . & . & . & . & . & . & . & & & . & & & 304 \\
\hline
\end{tabular}

\section{INTRODUCTION}

Macaranga Thou. (Euphorbiaceae, tribe Acalyphae, subtribe Mercurialinae) is a genus of $c .280$ species with a paleotropical distribution, stretching from West Africa through the Oriental Region to the Fidji-Islands (Whitmore, 1969). Macaranga is the world's largest genus of pioneer trees (Whitmore, 1979a). Seventy percent of the 27 West Malaysian Macaranga species are characteristic of secondary habitats such as roadsides; only seven species are restricted to primary forest. In SE Asia a high percentage of Macaranga species live in close association with ants. The centre of their distribution is in the tropical rainforest area in Peninsular Malaysia, Borneo and Sumatra. Macaranga is a very diverse genus, comprising the species ranging from those not regularly inhabited by ants to obligate myrmecophytes. As far as we know Crematogaster borneensis dominates the symbiosis in West Malaysia. However, this ant is highly variable in size and colour and more than one species may be involved in these forms (Longino, personal communication). We collected another species, mainly from $M$. hypoleuca, which was identified as $C$. decamera by J. Longino. All these ants belong to the subgenus Decacrema which is easily identified by its 10 -segmented antennae; within the subgenus, however, the taxonomic relations are still obscure. In addition, in some $M$. puncticulata Gage specimens we collected a Camponotus (Colobopsis) sp. The only myrmecophytic species in Thailand (M. motleyana subsp. griffithiana (Muell. Arg) Whitmore) was also colonized by a (different) Camponotus (Colobopsis) sp. In Borneo we found at least one more Crematogaster species associated with Macaranga trees (especially with $M$. kingii Hook f.).

In Peninsular Malaysia nine out of the 27 Macaranga species are ant-inhabited, mostly by Crematogaster borneensis. The ants live in the hollow stem of the plants and obtain food in form of food bodies produced by the plants and honeydew from scale insects kept inside the stems. These scales are specific for the association and are only found in inhabited Macaranga plants. The ant species is totally dependent on the host plant and does not survive away from it (Fiala \& Maschwitz, 1990). The ants protect their host plants against herbivore damage and vine infestation (Fiala et al., 1989). The Macaranga-C. borneensis system can be regarded as equivalent to myrmecophytic associations in Africa and America (Fiala, Maschwitz \& Tho, 1991).

Whitmore (1969) discussed some aspects of species evolution in Macaranga and stressed the suitability of this genus for the study of speciation. He did not, however, consider the ant-association. The full range of Macaranga species, from those which are not regularly associated with ants to obligate myrmecophytes, 
makes this genus especially suitable for the study of interspecific variation and evolution of myrmecophytism.

Why are most Macaranga species not colonized by ants? Do myrmecophytic Macaranga species offer physiological or morphological attractions for ants which are missing in non-myrmecophytes or do these uninhabited species also possess predispositions for myrmecophytism? In this respect, the presence or absence of extrafloral nectaries (EFNs), food bodies and nesting space (domatia) in nonmyrmecophytic Macaranga could be especially important. In this paper we discuss the simplest and most widespread adaptation of plants to attract ants: the occurrence of extrafloral nectaries.

The term extrafloral nectaries refers to nectaries that are not involved in pollination. The secreted fluids contain sugar and amino acids and are fed upon by many ant species. The immense structural variability of EFNs and their occurrence in different plant taxa have been reviewed (e.g. Bentley, 1977; Elias, 1983). Their adaptive significance has been controversial for decades. In recent years studies have shown that ants visiting EFNs often protect plants against herbivores (review Buckley, 1982; Beattie, 1985; Huxley, 1986; Keeler, 1989) although protection is not universal. Much variation exists in the effectiveness of nectaries as indirect antiherbivore defences (overview Keeler, 1989). Beattie (1985) suggests that this type of defence may be favoured only under certain conditions (particular habitats, prey densities etc.). Little information is available on Macaranga species which have no highly specialized relationship with ants. So far only one study exists on the efficacy of EFNs in attracting ants which might protect these Macaranga plants against herbivory (Whalen \& Mackay, 1988).

EFNs have been recorded from at least 68 angiosperm families (Elias, 1983) in more than 2200 species (Keeler, 1989). They occur in myrmecophytes as well as in plants with facultative relationships to ants. We here present an overview on the occurrence and abundance of EFNs in the genus Macaranga in Malaysia and discuss their significance as possible predispositions of Macaranga plants for the evolution of myrmecophytes in this genus.

\section{MATERIAL AND METHODS}

The investigations were carried out in West Malaysia during six units covering a total of 16 months and on a visit to Sabah/Borneo. In the field we studied a total of over 1000 plants of 26 Macaranga species, mainly from secondary habitats. Further information on the other West Malaysian as well as Bornean Macaranga species was gathered on herbarium specimens from the extensive material of the Forest Research Institute Malaysia (FRIM) at Kepong, Selangor.

In addition plants cultivated in the greenhouse in Frankfurt were used for morphological studies.

For comparison we also studied presence of EFNs in the closely related genus Mallotus Lour. and in other common Malaysian euphorb genera occurring in the same habitats, such as Endospermum Benth., Croton Linn. and Sapium R.Br.

In all Macaranga species we registered the presence of ants and specificity and degree of their association with the plants. Voucher specimens of ants are held in the collection of B.F., the Zoology Department, University of Frankfurt, FRG 
and FRIM, Malaysia. Most Malaysian ant species cannot be named confidently at the specific level. Unidentified ant species were discriminated by numbers.

Plants were checked for colonization with ants and presence of ant-related structures such as EFNs, food bodies and domatia. For Macaranga species, of which only a few specimens were found, we tried to gain additional information from original descriptions in the literature.

EFN-morphology was investigated by scanning electron microscopy (SEM) of fresh leaf material (Hitachi S 500, $5 \mathrm{kV}$ ) and light microscopy of paraplast leaf sections.

We carried out quick field tests on EFN-secretions of at least ten plants each of several Macaranga species. Test sticks for medical purposes (Albu- and Dextrostix, MERCK) were used for semi-quantitative tests on sugar concentration of nectar. These sticks, however, give a maximum reading of only $2.5 \mathrm{~g}^{-1}$ glucose and do not differentiate higher concentrations or different sugars. To verify the results obtained by Dextrostix, the nectar secretion of three species (M. triloba (Bl.) Muell. Arg., M. hypoleuca Muell. Arg., M. tanarius (L.) Muell. Arg.) was tested by the very sensitive anthrone method of Mokrasch (1954) which also identifies sucrose and fructose in concentrations as low as $0.05 \mu \mathrm{M}$.

Identifications of Macaranga were made after Whitmore (1967, 1973, 1975). Voucher specimens are deposited in collections of B.F. and in the herbarium of FRIM.

\section{RESULTS}

\section{Glands on the leaf margin}

All the myrmecophytic Macaranga species investigated have conspicuous structures along the leaf margins, which resemble nectaries (Fig. 1) and secrete a water-like liquid, especially in young leaves. These structures are also present in most uninhabited species - especially conspicuous in $M$. gigantea Muell. Arg. and M. diepenhorstii Muell. Arg. (Fig. 2) but only weakly developed in $M$. conifera (Zoll.) Muell. Arg and M. heynei I. M. Johnston. In these two species we only rarely observed secretion from these structures.

\section{Structure}

The structures at the leaf margins resemble EFNs described from other plants (Fig. 3). The internal structure studied by transverse and longitudinal sections also showed the typical nectary structure (overview Elias, 1983). In the two myrmecophytic species investigated ( $M$. triloba and M. hypoleuca), however, xylem elements seem to dominate compared to the non-myrmecophyte $M$. tanarius, which has more phloem elements.

\section{Glands on the leaf blade}

Some Macaranga species have EFNs on the lamina in addition to the marginal structures. All obligatory myrmecophytic Macaranga species, however, lack EFNs on the leaf surface. Additional EFNs on the lamina occur only in those inhabited species, which we regard as transitional. Those species do not seem to be fully 


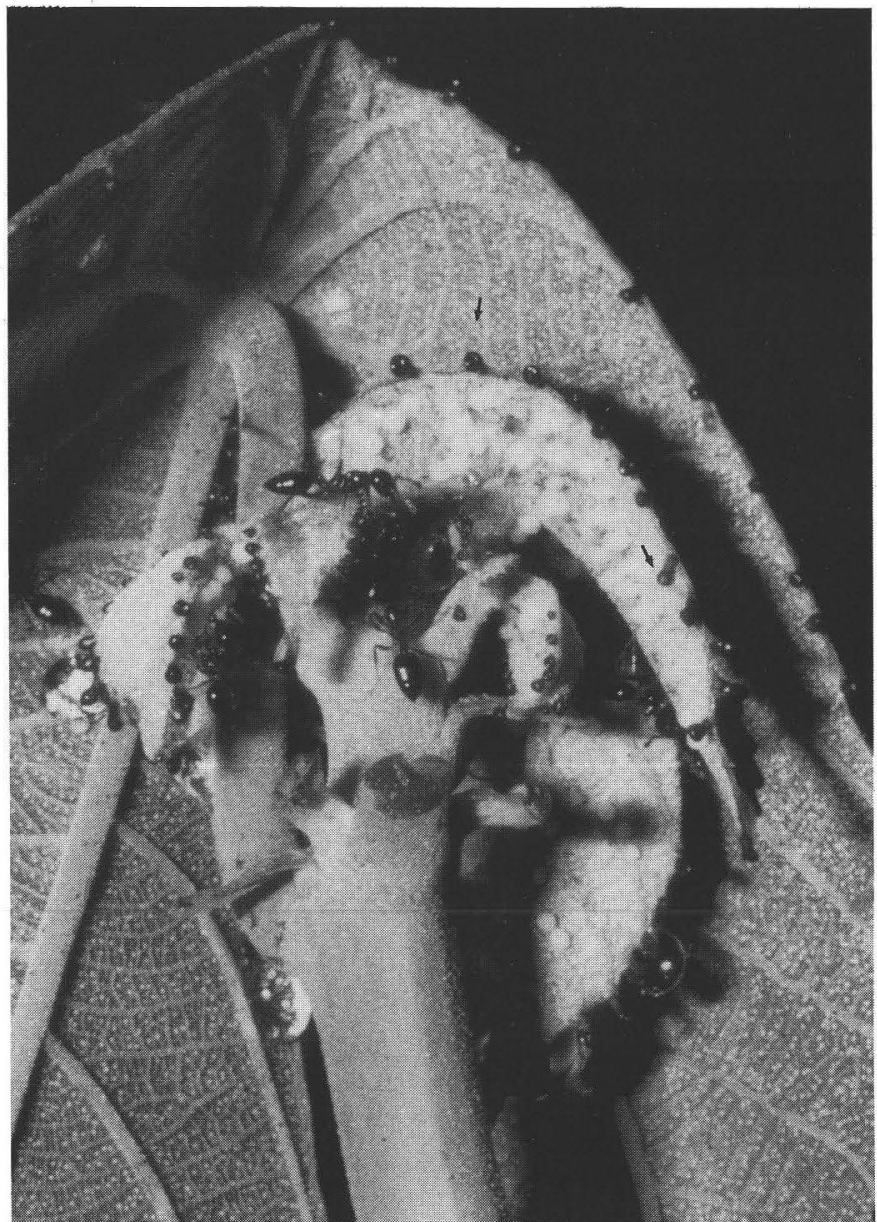

Figure 1. Marginal glands on leaves of $M$. hypoleuca.

adapted to ant-inhabitation because their stems do not become hollow as in the other Macaranga myrmecophytes, and therefore their percentage of antcolonization is lower.

The Bornean $M$. rostrata Heine, for example, seems to be a facultatively colonized species, since only specimens from Sarawak, but not from Sabah, were recorded as ant-inhabited (Whitmore, 1973). Macaranga rostrata has two glands on the basis of the leaf. In another transitional species, $M$. hosei King ex Hook f., additional EFNs occurred only on about $80 \%$ of the plants investigated $(\mathcal{N}=$ 42), and only temporarily. Macaranga hosei has two small EFNs on the leaf surface near the leaf insertion (Fig. 5A) in addition to the marginal structures (sometimes reduced to only one gland, Fig. 4). These laminar structures occur, however, only in young saplings and are not usually present in plants taller than $1 \mathrm{~m}$. In contrast to other inhabited Macaranga species which are already colonized at a size of $10 \mathrm{~cm}$, only $15 \%$ of $M$. hosei plants are inhabited below a size of $70 \mathrm{~cm}(\mathcal{N}=114)$. It is usually when the plant is about this size that the EFNs on the leaf lamina regress and food body production starts. 

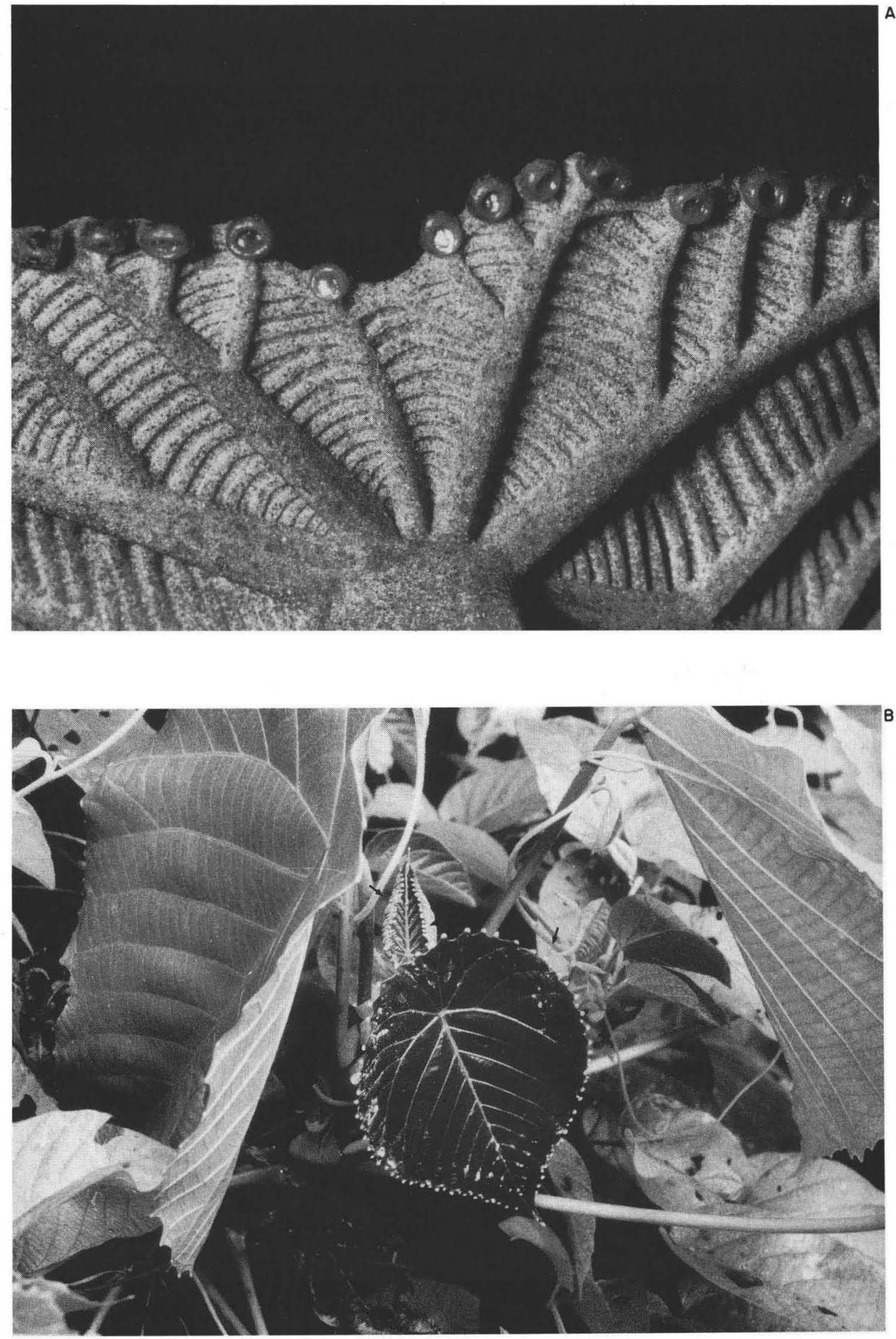

Figure 2. EFN on the leaf margins of the non-myrmecophytes A, M. gigantea and B, M. diepenhorstii. 

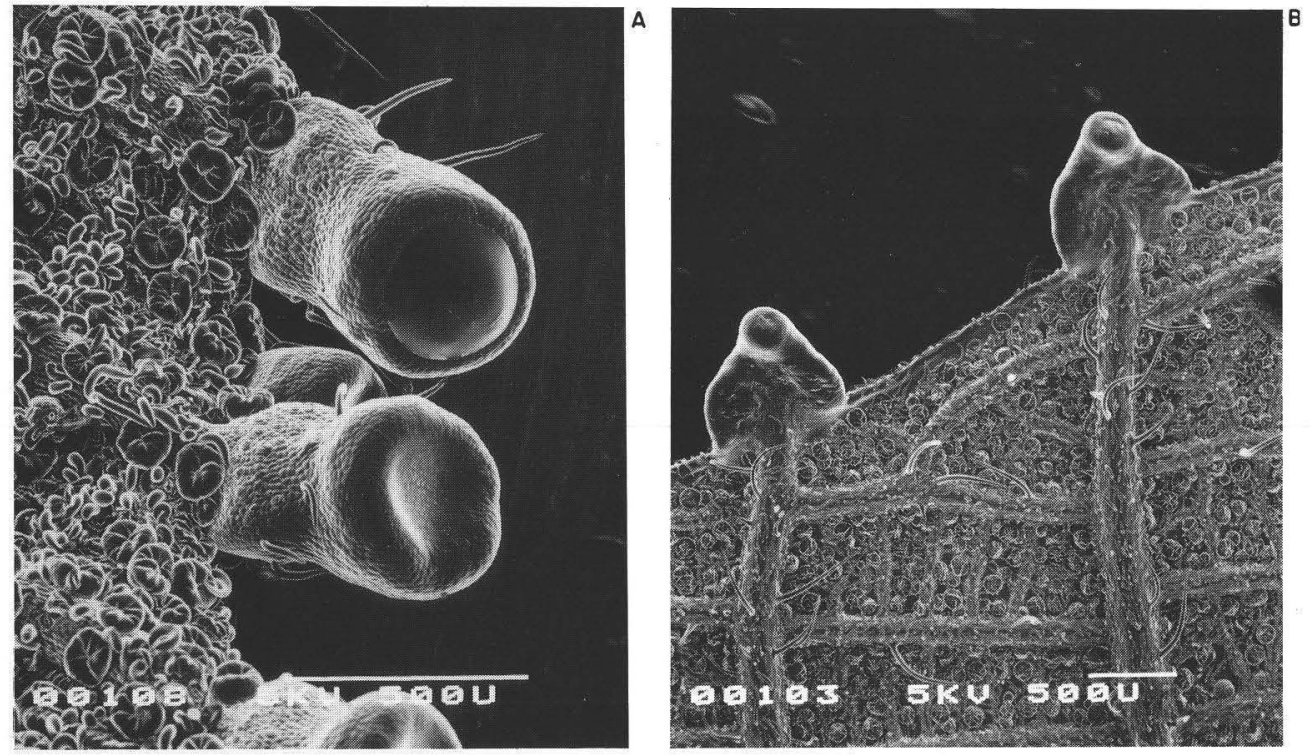

Figure 3. SEM of leaves of A, M. hypoleuca and B, M. triloba, showing glands on the margins (Scale bar $=500 \mu \mathrm{m})$.

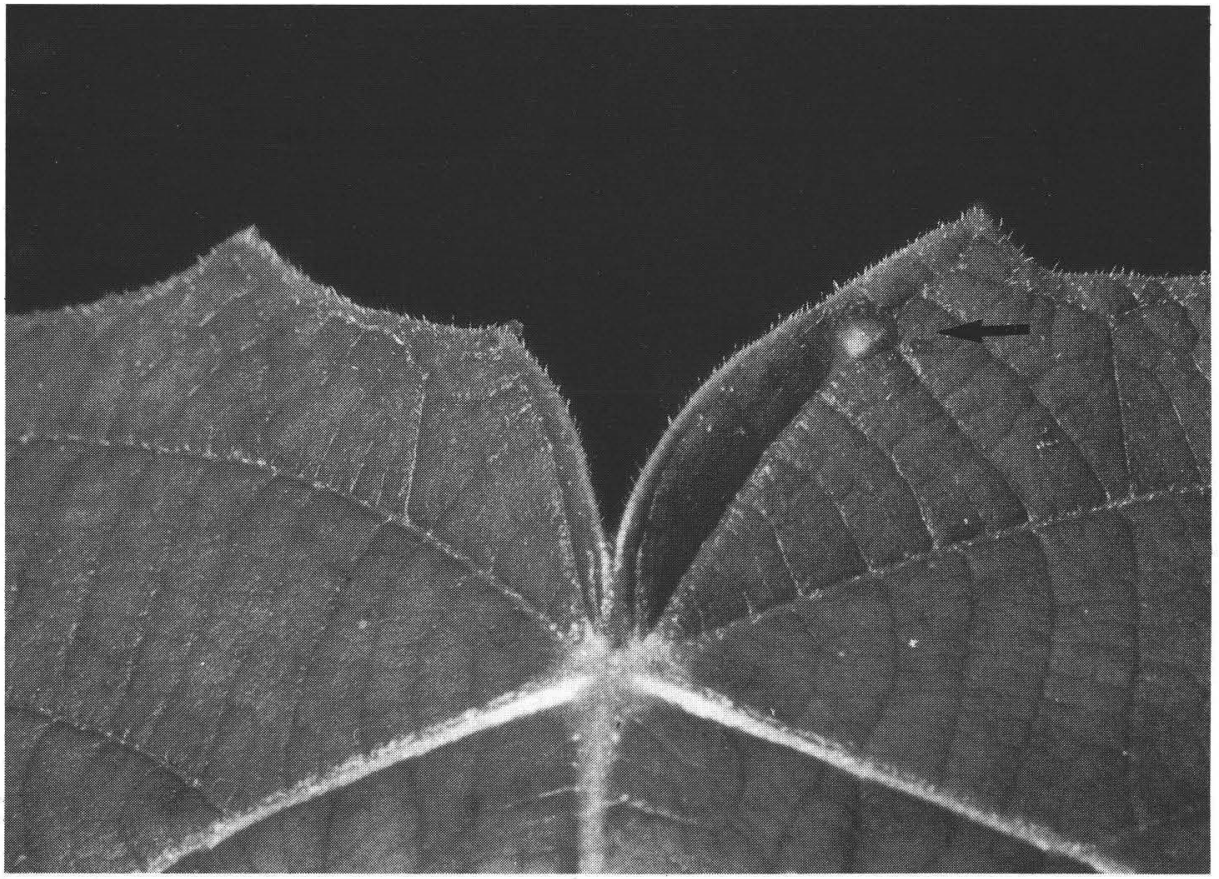

Figure 4. EFN on the leaf of $M$. hosei. 

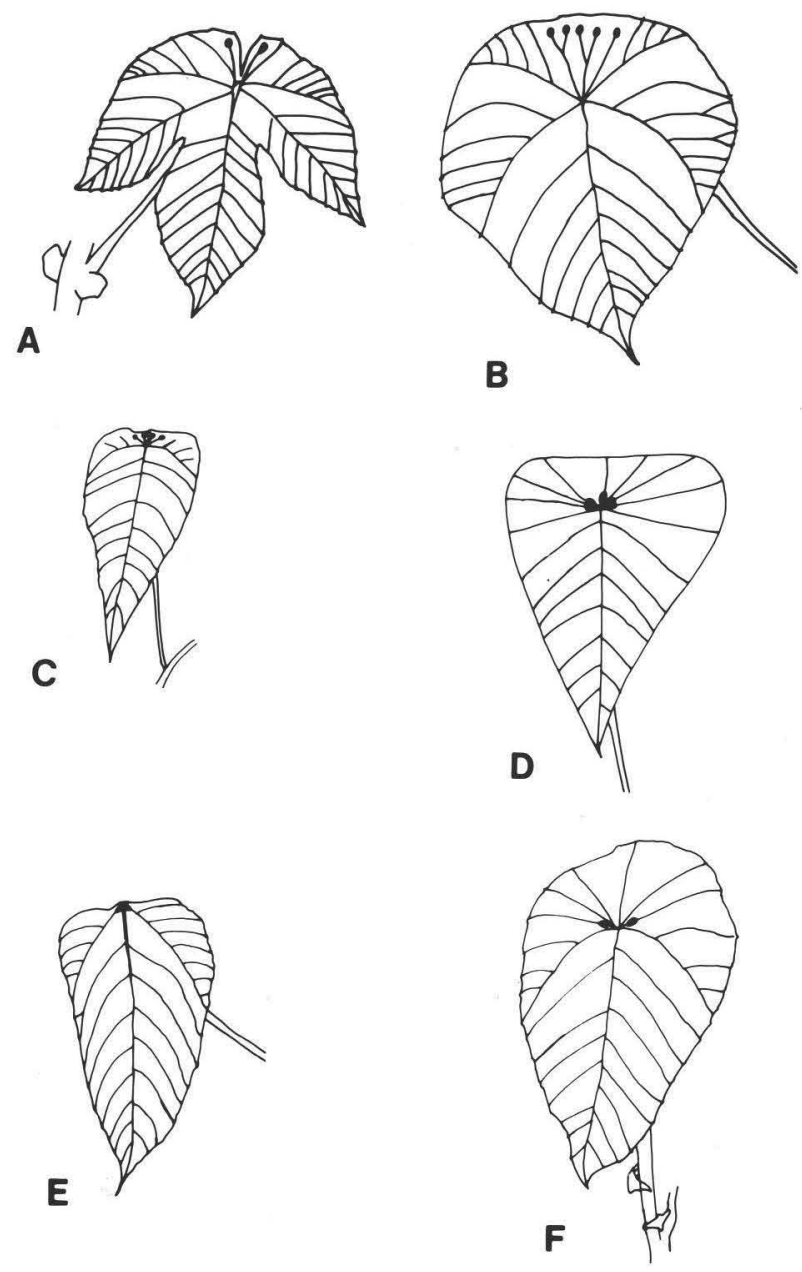

Figure 5. Locations of EFN on leaves of different Macaranga species. A, M. hosei; B, M. tanarius; C, $M$. conifera; D, $M$. denticulata; E, M. heynei; F, M. indica. B-F are non-myrmecophytic species.

Small EFNs at the leaf surface were also found in young plants of $M$. pruinosa (Miq.) Muell. Arg., which is ant-inhabited, but the degree of colonization is rather low (Fiala, Maschwitz \& Tho, 1991). Only about half of the plants had these glands and, as in $M$. hosei, all taller plants ( $>1.2 \mathrm{~m}$ ) always lacked EFNs on the leaf surface.

With the exception of this temporarily limited occurrence, additional EFNs on the leaf surfaces exist otherwise only in non-myrmecophytic Macaranga (cf. Table 1).

In $M$. gigantea there is no fixed number or location of EFNs but about 20 EFNs are scattered over the entire upper leaf surface.

Macaranga tanarius has five EFNs on the upper leaf surface at the end of main nerves, near the stalk insertion of the peltate leaf (Fig. 5B) but they are no longer present on leaves of trees taller than $4 \mathrm{~m}$.

Macaranga conifera has five EFNs at the base of the blade (Fig. 5C) which, in 
course of plant growth, are reduced to two glands; they are persistent also on tall trees.

A reduction of EFN number also takes place in $M$. denticulata (Bl.) Muell. Arg: 5-2 glands in younger plants on the upper surface of the peltate leaf (Fig. 5D) near stalk insertion; most larger trees without EFNs.

Macaranga heynei has two EFNs, also on tall trees at the base of the blade (Fig. $5 \mathrm{E}$ ) (rarely up to four glands on younger plants).

Macaranga indica Wight has two EFNs (younger plants have four, with variations on different leaves of the same plant, glands on the upperside at the insertion of the stalk (Fig. 5F)).

Macaranga lowii King ex Hook f., M. andamanica Kurz, M. baccaureifolia Airy Shaw has two glands on the upper side of the leaf near insertion of petiole.

In Borneo a further eight species with two EFNs on the leaf lamina occur (Table 1).

TABLE 1. Distribution of extrafloral nectaries on the leaf surface (in addition to marginal glands) in the genus Macaranga in Malaysia. (Species according to Whitmore 1975; M, myrmecophyte; (M), transitional species; sapl., only in saplings; ( ), only weakly developed; S, secondary habitats; P, primary forests; MA, Peninsular Malaysia; B, Borneo)

\begin{tabular}{|c|c|c|c|c|}
\hline Species & $\begin{array}{l}\text { Association } \\
\text { with ants }\end{array}$ & $\begin{array}{l}\text { No. of EFNs } \\
\text { per leaf }\end{array}$ & $\begin{array}{c}\text { Main } \\
\text { habitat }\end{array}$ & Distribution \\
\hline \multicolumn{5}{|c|}{ 1. § Pachystemon sensu stricto } \\
\hline M. aetheadenia & M & - & $\mathrm{P}, \mathrm{S}$ & B \\
\hline M. beccariana & M & - & S, (P) & B \\
\hline M. calcicola & M & - & ? & B \\
\hline M. constricta & M & - & $\mathrm{P}, \mathrm{S}$ & MA \\
\hline M. havilandii & M. & - & $\mathrm{P},(\mathrm{S})$ & B \\
\hline M. hullettii & M & - & $\mathrm{S}, \mathrm{P}$ & MA, B \\
\hline M. hypoleuca & M & - & $\mathrm{S}, \mathrm{P}$ & MA, B \\
\hline M. indistincta & M & - & $\mathrm{P},(\mathrm{S})$ & B \\
\hline M. kingii & M & - & $\mathrm{S}, \mathrm{P}$ & MA, B \\
\hline M. lamellata & M & - & $\mathrm{P}$ & B \\
\hline \multicolumn{5}{|l|}{ M. motlevana } \\
\hline subsp. griffithiana & M & - & $\mathrm{S},(\mathrm{P})$ & MA, B \\
\hline M. petanostyla & M & - & $\mathrm{P}$ & B \\
\hline M. trachyphylla & M & - & $\mathrm{P}, \mathrm{S}$ & $\mathrm{B}$ \\
\hline M. triloba & M & - & $\mathrm{S},(\mathrm{P})$ & MA, B \\
\hline M. depressa & - & - & ? & B \\
\hline M. quadricornis & - & - & $\mathrm{P}, \mathrm{S}$ & MA, B \\
\hline$M$. recurvata & - & - & $\mathrm{S}, \mathrm{P}$ & $\mathrm{MA}, \mathrm{B}$ \\
\hline \multicolumn{5}{|c|}{ 2. § Pachystemon sensu lato } \\
\hline M. caladiifolia & M & - & $\mathrm{S}, \mathrm{P}$ & MA, B \\
\hline M. puncticulata & $(\mathbf{M})$ & - & $\mathrm{S}, \mathrm{P}$ & MA \\
\hline M. rostrata & (M) & 2 (?) & $\mathrm{P},(\mathrm{S})$ & B \\
\hline M. curtisii & - & - & $\mathrm{P}, \mathrm{S}$ & MA \\
\hline M. sarcocarpa & - & - & ? & B \\
\hline \multicolumn{5}{|c|}{ 3. $\S$ The $M$. pruinosa group } \\
\hline M. hosei & $(\mathbf{M})$ & 2 (sapl.) & $\mathrm{S}, \mathrm{P}$ & MA, B \\
\hline M. pearsonii & (M) & $?$ & $\mathrm{~S},(\mathrm{P})$ & B \\
\hline M. pruinosa & (M) & 2 (sapl.) & $\mathrm{S}$ & $\mathrm{MA}, \mathrm{B}$ \\
\hline M. puberula & (M) & ? & $\mathrm{P}, \mathrm{S}$ & B \\
\hline \multicolumn{5}{|l|}{ 4. § Pseudo-Rottlera } \\
\hline M. andamanica & - & 2 & $\mathrm{P},(\mathrm{S})$ & MA \\
\hline M. baccaureifolia & - & 2 & $\mathrm{P}$ & $\mathrm{MA}, \mathrm{B}$ \\
\hline M. brevipetiolata & - & 2 & $\mathrm{P},(\mathrm{S})$ & B \\
\hline
\end{tabular}


TABLE 1 -continued

\begin{tabular}{|c|c|c|c|c|}
\hline Species & $\begin{array}{l}\text { Association } \\
\text { with ants }\end{array}$ & $\begin{array}{l}\text { No. of EFNs } \\
\text { per leaf }\end{array}$ & $\begin{array}{c}\text { Main } \\
\text { habitat }\end{array}$ & Distribution \\
\hline M. fulva & - & 2 & $\mathrm{P}$ & B \\
\hline M. lowii & - & 2 & $\mathrm{P},(\mathrm{S})$ & $\mathrm{MA}, \mathrm{B}$ \\
\hline M. praestans & - & 2 & $\mathrm{P}$ & $\mathrm{B}$ \\
\hline M. rarispina & - & 2 & $\mathrm{P}$ & B \\
\hline M. repandodentata & - & $?$ & $\mathrm{P}$ & B \\
\hline$M$. setosa & - & $一 ?$ & $\mathrm{P}$ & MA \\
\hline M. strigosissima & - & 2 & $\mathrm{P}$ & B \\
\hline \multicolumn{5}{|l|}{ 5. § Stachyella } \\
\hline M. amissa & - & - & $\mathrm{P}, \mathrm{S}$ & $\mathrm{MA}, \mathrm{B}$ \\
\hline M. conifera & - & $5-2$ & $\mathrm{P}, \mathrm{S}$ & MA, B \\
\hline \multicolumn{5}{|l|}{ 6. § Javanicae } \\
\hline M. costulata & - & $4-2$ & $\mathrm{~S},(\mathrm{P})$ & B \\
\hline M. heynei & - & 2 & $\mathrm{~S}$ & MA \\
\hline M. kinabaluensis & - & 2 & $\mathrm{P}$ & B \\
\hline \multicolumn{5}{|l|}{ 7. $\S$ Winklerianae } \\
\hline M. winkleri & $\mathbf{M}$ & - & $S$ & B \\
\hline M. winkleriella & M & - & $?$ & B \\
\hline \multicolumn{5}{|l|}{ 8. $\S$ Adenoceras } \\
\hline$M$. endertii & - & 2 & $\mathrm{P}$ ? & B \\
\hline \multicolumn{5}{|c|}{ 9. Species which are individually distinctive } \\
\hline M. denticulata & - & $5-2-0$ & $\mathrm{~S}$ & MA, B \\
\hline M. diepenhorstii & - & - & $\mathrm{S},(\mathrm{P})$ & MA \\
\hline M. gigantea & - & (up to 20) sapl. & $\mathrm{S},(\mathrm{P})$ & MA, B \\
\hline M. gigantifolia & - & ? & ? & B \\
\hline$M$. indica & - & 5-2 & $\mathrm{S}, \mathrm{P}$ & MA \\
\hline M. tanarius & - & 5-2 (sapl.) & $\mathrm{S}$ & MA, B \\
\hline M. trichocarpa & -- & 2 & $\mathrm{~S}, \mathrm{P}$ & MA, B \\
\hline
\end{tabular}

\section{Contents of secretions}

In the myrmecoph tic Macaranga species we tested the marginal structures, in species with additional laminar EFNs we tested both types of glands. There was usually no difference in the amount of sugar between these types on one plant.

Owing to insufficient liquid secretion it was not possible to obtain data for all investigated species, but all tested non-inhabited species secreted sugarcontaining fluids albeit of rather low concentration (Table 2). Surprisingly, the

TABLE 2. Sugar content of liquids secreted by glands on Macaranga leaves. (Anthrone method used only for the first three species. M, Myrmecophytic species)

\begin{tabular}{lcc}
\hline Species & $\begin{array}{c}\text { Quick tests } \\
\text { (maximum reading } 2.5 \mathrm{~g} \mathrm{l}^{-1} \text { ) }\end{array}$ & $\begin{array}{c}\text { Anthrone } \\
\text { method }\end{array}$ \\
\hline $\begin{array}{l}\text { M. triloba } \mathrm{M} \\
\text { M. hypoleuca } \mathrm{M}\end{array}$ & $\begin{array}{c}\text { No sugar } \\
\text { No sugar }\end{array}$ & $\begin{array}{c}\text { No sugar } \\
\text { No sugar }\end{array}$ \\
M. tanarius & $1.7-2.5$ & $9-14$ \\
M. conifera & $1.3-2.5$ & - \\
M. curtisii & $0.7-1.3$ & - \\
M. diepenhorstii & $0.7-2.5$ & - \\
M. gigantea & $0.9-2.5$ & - \\
M. indica & $0.5-1.3$ & - \\
$M$. recurvata & $0.7-1.3$ & \\
\hline
\end{tabular}




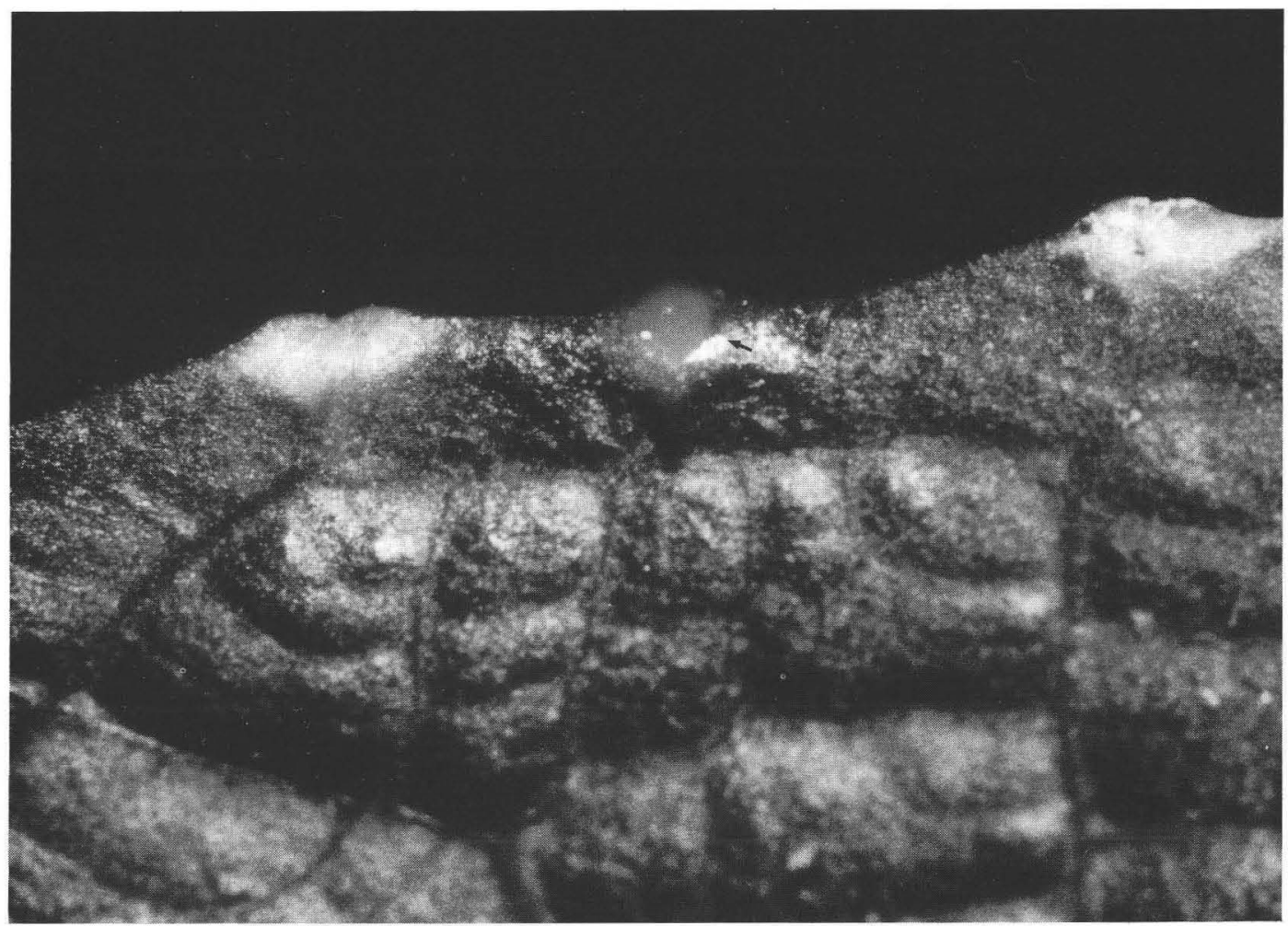

Figure 6. EFN on the leaf margin of the non-myrmecophyte $M$. diepenhorstii.

quick tests failed to measure sugar in the liquids of almost all tested myrmecophytic species (M. hypoleuca, M. hulletti, M. motleyana subsp. griffithiana and $M$. triloba, $\mathcal{N}=50$ ). Also, the very sensitive anthrone test after Mokrasch (1954) failed to detect any sugars in the gland secretions of these species. On only four occasions (on small saplings of $M$. hulletti and $M$. triloba resp., which were not yet inhabited) were traces of sugar $\left(0.5 \mathrm{~g} \mathrm{l}^{-1}\right)$ found.

In all other species in which insufficient liquid secretion prevented tests for sugar, however, we observed various ant species visiting the EFNs at the leaf margins. This gave indirect evidence for sugar secretion. Ants were also observed on the two laminar EFNs of $M$. hosei saplings.

In $M$. diepenhorstii Muell. Arg. two different forms of EFNs are located at the leaf margin: the ants take much more notice of the red, rounder shining EFNs (Fig. 6, arrow) situated between green ones. A similar difference (not in colour but in size) is observed in $M$. tanarius. In both cases the secreted liquids actually contained different amounts of sugar (in the smaller glands about half as much as in the larger ones).

\section{Ant visit}

In all myrmecophytic species only the inhabiting Crematogaster ants were found on the leaves. The EFNs of the non-myrmecophytic Macaranga species were visited day and night by various ant species. A total of 28 ant species out of 15 genera was found on the Macaranga leaves during the study period (Table 3). 


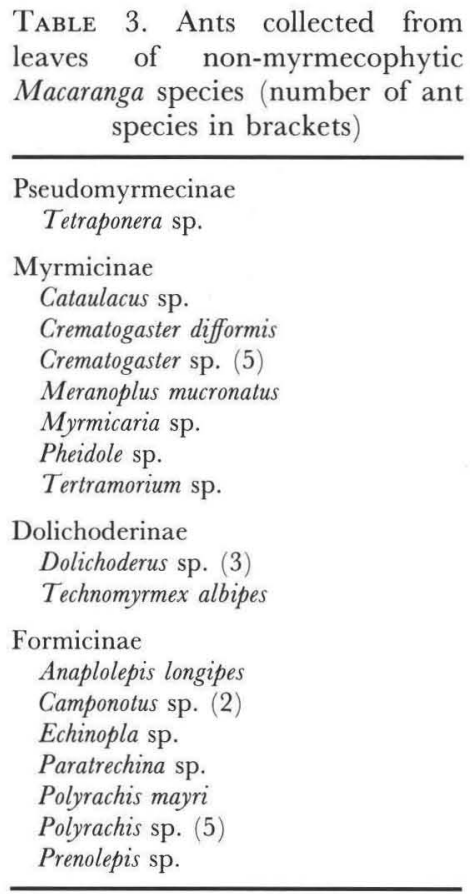

Most Malaysian ant species cannot be named confidently at the specific level. From most Macaranga species we collected only small samples, but on the more thoroughly studied $M$. tanarius we found at least 20 different ant species at one study site. Crematogaster species were numerically dominant $(42 \%$ of the visiting ants $(\mathcal{N}=102))$. Many of these ants were also found on other plant species in the vicinity (e.g. on the related Endospermum and Mallotus). We found no evidence for any specific relationship between certain non-myrmecophytic Macaranga species and the visiting ant species.

\section{Comparison with other Euphorbiaceae in West Malaysia}

Mallotus

Marginal glands as present in Macaranga also occur in the closely related genus Mallotus but are much less conspicuous. Some species have two large glands at the stalk insertion on the upper leaf surface (Fig. 7) and often have in addition up to 12 smaller glands scattered over the lamina, mostly near the margin at the end of minor veins. We found EFNs in 14 of the 27 Mallotus species in West Malaysia (Table 4). They are visited by many different ant species. Tests with Dextrostix yielded the maximum possible reading of $2.5 \mathrm{~g}$ glucose $1^{-1}$ at the two large glands but a lower sugar concentration at the marginal glands.

\section{Endospermum}

The only Malaysian species, E. diadenum Airy Shaw, has up to 12 glands on the under surface of the leaves. Their exact position varies from on the apex of the petiole to the base of the blade. The glands produce a sweet exudate 


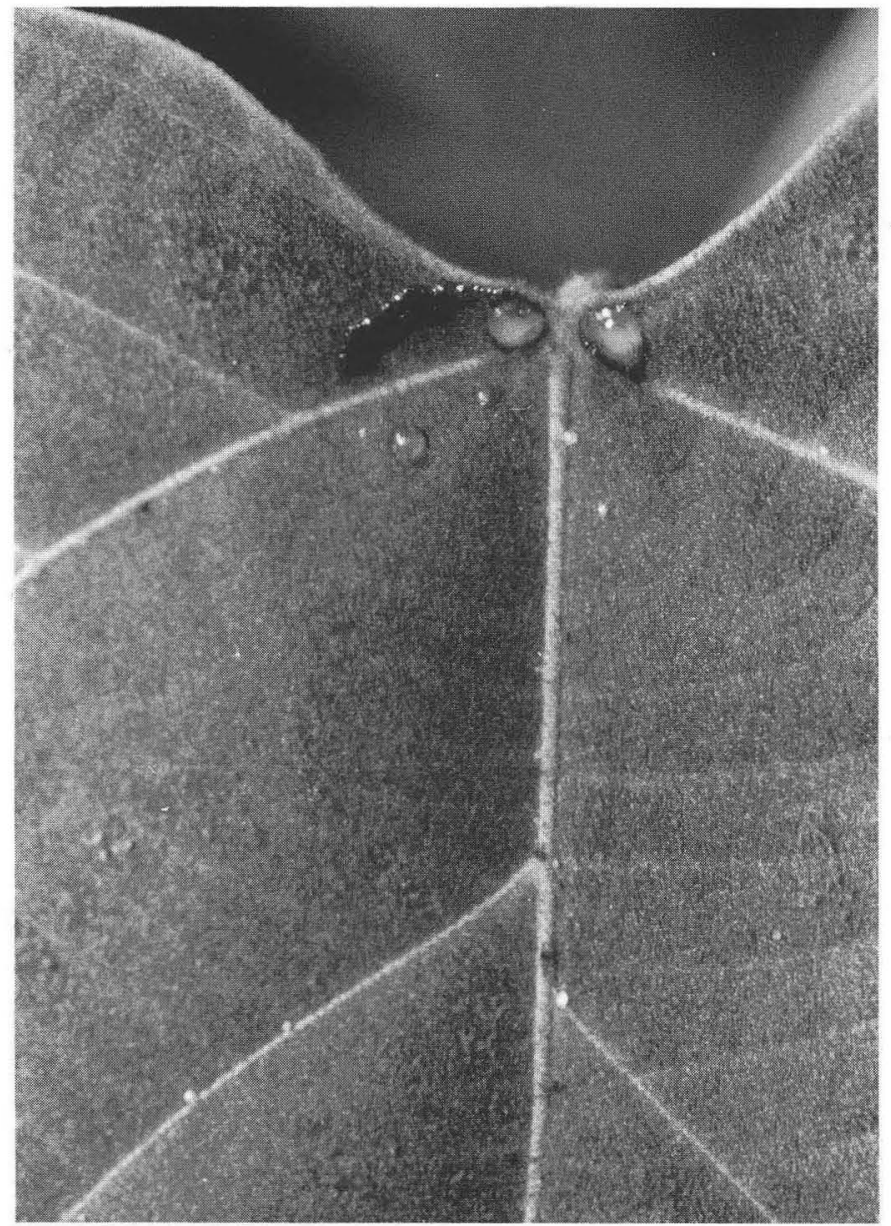

Figure 7. EFN of Mallotus paniculatus.

(maximum reading of Dextrostix test) which is fed upon by various ants. On several specimens we found more than 25 ants per leaf taking up nectar - in total more than 200 ants on one plant.

\section{Croton}

In this genus nine of the 11 investigated species occurring in Peninsular Malaysia had EFNs (Table 5). A pair of glands is located on the undersurface of the leaves near the stalk insertion. These nectaries, however, were not visited by many ants despite the high sugar content of their exudates (Dextrostix maximum reading). On only half of the 20 trees of the most common $C$. caudatus Geisel in one study area were ants found at the EFNs and usually no more than one or two per branch (maximum of five ants per branch).

\section{Sapium}

Three of the four Malaysian species possess EFNs. Two Sapium species occur in secondary and primary forest, one prefers riverbanks and swamps. Sapium 
TABLE 4. Distribution of EFN in the genus Mallotus in West Malaysia. (Species after Whitmore, 1973; abbreviations as in Table 1; L, restricted to limestone)

\begin{tabular}{lcl}
\hline Species & EFN per leaf & Main habitat \\
\hline M. barbatus & - & $\mathrm{S}, \mathrm{L}$ \\
M. bracteatus & - & $\mathrm{L}$ \\
M. brevipetiolatus & $?$ & $\mathrm{~L}$ \\
M. cuneatus & 2 & $\mathrm{~L}$ \\
M. dispar & 2 & $\mathrm{~L}$ \\
M. eximius & 2 & ? \\
M. eriocarpus & $(2)$ & $\mathrm{L}$ \\
M. floribundus & 2 & $\mathrm{~S}$, rivers \\
M. griffithianus & $(2)$ & $\mathrm{P}$ \\
M. kingii & $(2)$ & $\mathrm{P}, \mathrm{S}$ \\
M. korthalsii & - & $\mathrm{S}$ \\
M. lackeyi & - & $\mathrm{S}$ \\
M. leucodermis & 2 & $\mathrm{P}, \mathrm{S}$ \\
M. macrostachys & 2 & $\mathrm{~S}, \mathrm{P}$ \\
M. miquelianus & - & $\mathrm{P}$ \\
M. moritzianus & $?$ & $\mathrm{P}$ ? \\
M. muticus & - & $\mathrm{P}$ \\
M. oblongifolius & 2 & $\mathrm{~S}$ \\
M. paniculatus & 2 & $\mathrm{~S}$ \\
M. peltatus & - & $\mathrm{P}$ \\
M. penangensis & 2 & $\mathrm{P}$ \\
M. phillipensis & 2 & $\mathrm{~S}$ \\
M. repandus & - & $\mathrm{L}$ \\
M. subpeltatus & - & $\mathrm{P}$ \\
M. subcuneatus & - & $\mathrm{P}$ ? \\
M. tiliifolius & - & $\mathrm{S}$ \\
M. wrayi & $(2)$ & $\mathrm{P}$ \\
\hline & &
\end{tabular}

TABLe 5. Distribution of EFN in the genus Croton in West Malaysia (species after Whitmore, 1973; abbreviations as in Table 1)

\begin{tabular}{lcl}
\hline Species & EFN per leaf & Main habitat \\
\hline C. argyratus & 2 & $\mathrm{P}, \mathrm{S}$ \\
C. caudatus & 2 & $\mathrm{~S}, \mathrm{P}$ \\
C. cascarilloides & 2 & $\mathrm{~L}$ \\
C. ensifolius & - & $\mathrm{R}$ ivers \\
C. erythrostachys & 2 & $\mathrm{P}, \mathrm{S}$ \\
C. heterocarpus & - & Mangrove \\
C. hirtus & $(2)$ & ? \\
C. kelantanicus & 2 & ? \\
C. laevifolius & 2 & $\mathrm{~S}$, rivers \\
C. lucidus & 2 & ? \\
C. macrocarpus & 2 & Swamp \\
\hline
\end{tabular}

baccatum Roxb. is locally common with Endospermum but was, in contrast, only rarely found with ants. The Sapium species without EFNs is restricted to limestone.

\section{DISCUSSION}

For an association with ants the plants' offer of food and nesting space is especially important. EFNs have often been interpreted as a feature of the 
evolutionary precursors of myrmecophytes (e.g. Janzen, 1966; Wilson, 1971; McKey, 1989). Those possible predispositions to a myrmecophytic way of life also exist in Macaranga species not regularly associated with ants. As this study shows, most of these possess EFNs. In all species investigated EFN-like structures are present along the leaf margins and in some species additionally on the leaf surface. EFNs offer an energy source in the form of sugar and amino acids which are in high demand by ants (overview Bentley, 1977).

Surprisingly, it was only in the non-myrmecophytic Macaranga that the liquid secreted by the glands contained sugars.

Anatomical studies showed the dominance of xylem elements in the glands of myrmecophytic Macarangas. This could be an indication that the secretion will be very diluted and will have a high water content. This gutation can facilitate nutrient supply of meristematic tissue in the stem under conditions of lowered transpiration. This happens mainly in the early morning when relative humidity is very high. The glands would then function as hydathodes. EFNs and hydathodes are closely related (Fry-Wyssling, 1935; Esau, 1969; Elias \& Gelband, 1977) but the former have more phloem elements. The transitional function is demonstrated in $M$. diepenhorstii and $M$. tanarius, where both types are found side by side.

In myrmecophytic Macaranga species, ants obtain food from the plant in the form of food bodies and, in addition, nutritive plant fluids via scale insects cultivated inside the stems. Honeydew may be more attractive than nectar since the gut symbionts of the scales enrich the plant sap with sterols and vitamins (Brian, 1977). On the other hand, Becerra \& Venable (1989) argue that nectar might be superior to honeydew. They hypothesize that EFNs may function to defend plants against ant-homoptera mutualism. However, this does not seem to be the case in the obligate myrmecophytic symbioses. In most of these associations ants cultivate homopterans and EFNs are absent (e.g. in Macaranga, Cecropia, Barteria, Triplaris, exception: Acacia, Leonardoxa africana; review Buckley, 1982; Beattie, 1985). The hypothesis of superiority of extrafloral nectar to honeydew remains to be tested in facultative associations, but preliminary observations in Malaysia did not support this for Macaranga and Mallotus species where homopterans were kept on the plants despite the presence of EFNs (Fiala, 1990).

\section{Ecology}

The reduction of nectar production by EFNs seems to be of biological advantage in ant-inhabited Macaranga: firstly, assimilates of the plant are saved. Secondly, it may also stabilize the maintenance of the specific association: open presentation of nectar by EFNs would certainly attract other ant species not associated with Macaranga which could be a threat for the obligatory inhabiting C. borneensis ants. The food rewards offered by the plants are easily accessible only for $C$. borneensis: the scales live inside the hollow stems and the food bodies at least in five myrmecophytic Macaranga species are rather protected under stipules and accessible only for small ants. Other ant species could pose a danger for C. borneensis, either by direct attack or by preventing C. borneensis from leaving the stem interior. In either case the protective function of $C$. borneensis for the plant (herbivore and vine defence) would be weakened. 
Despite the incompleteness of our inventory of visiting ants the large number of ant species visiting non-myrmecophytes and the low specificity of the association is evident. Each Macaranga species is visited by various species; often we observed several different species on one leaf at the same time. Similar observations were recorded by Whalen \& Mackay (1988) in New Guinea on three non-inhabited Macaranga species there.

Bentley's opinion (1977) that plants with EFNs are overrepresented in secondary habitats was supported by Schupp \& Feener's (1991) extensive survey on Panamanian forest plants. They found that ant defence (plants with EFNs and/or food bodies) was more common in gap species which is in agreement with our own survey on forest trees in Malaysia (Fiala \& LaFrankie, unpublished). The results of the present study, however, gave no consistent pattern for Macaranga and Mallotus species in this respect. Most of the Macaranga species not belonging to the section Pseudo-Rottlera grow in rather open habitats. Although they are often recorded for primary forest this information is not necessarily reliable, since a tree which is inhabiting a gap in a primary forest will often be recorded as primary forest tree.

Whitmore (1979b), however, is convinced that Macaranga species are mostly trees of secondary forest or gaps and riversides in primary forest. Only the species in the section Pseudo-Rottlera are real understorey trees of primary forest. Surprisingly, it is this section which comprises most species with EFNs on the leaf blade. The primary forest Macaranga are never inhabited by ants (own observations) and differ morphologically from the typical habitus of the Macaranga species in secondary habitats.

The section Pseudo-Rottlera is morphologically similar to the closely related genus Mallotus, a genus predominantly of closed forest. A few Mallotus species are found in natural clearings like most Macaranga species (Whitmore, 1973). For the Mallotus species in West Malaysia also no clear pattern of distribution of EFNs in relation to the habitat exists. Fourteen of the 25 investigated species possess EFNs. Two of these species are restricted to primary forest, four to open habitats, three are restricted to limestone, and for the rest no habitat preference is known. The occurrence and role of EFNs in primary forest still remain to be investigated.

Formation of EFNs should be favoured in open habitats, where costs of nectar production are relatively low, because of the high rate of photosynthesis for pioneer species in open habitats (e.g. for $M$. hypoleuca double as in primary forest species; Koyama, 1978). O'Dowd (1979) estimated for Ochroma pyramidale that nectar production represents only $1 \%$ of the total energy invested in each leaf.

Nevertheless, the plants are economical in formation of EFNs since these are usually only developed on young leaves and often only on saplings. In the myrmecophytic Macaranga species EFN structures that function as such are only present in the transitional species $M$. hosei, $M$. pruinosa and $M$. rostrata which are colonized at a later stage than the other myrmecophytes. Macaranga hosei seems to attract a variety of ants until it is colonized by its obligate mutualist. The same phenomenon has been described by McKey (1988) for Barteria where young plants which have not yet developed domatia have EFNs but larger plants lack them. Of the investigated Macaranga non-myrmecophytes only nine species also retain EFNs on taller plants: $M$. indica, $M$. heynei, $M$. conifera, M. lowii and five other species from the section Pseudo-Rottlera. However, there is 
also a tendency for the number of EFNs in adult trees to be reduced as shown in $M$. indica and $M$. conifera.

So far only two studies have been done on non-myrmecophytic Macaranga from Australia and New Guinea (Whalen \& Mackay, 1988; Mackay \& Whalen, 1991). The results of the studies, however, gave no uniform picture since only one of the three species investigated showed increased levels of herbivory when ants were excluded.

Our observations in Malaysia showed that heavy damage can occur on antvisited Macaranga plants with EFNs (Fiala et al., 1989, and unpublished work) but preliminary results indicate that ants also provide protection for Macaranga with EFNs. The biological function (e.g. protection) of EFNs in Macaranga will be treated in detail elsewhere (Grunsky et al., in prep.).

\section{Taxonomic distribution and evolution}

EFNs are common in the Euphorbiaceae (Elias, 1983; Schnell, Cusset \& Quenum, 1963). They are found on Macaranga species over their entire range. A compilation of data from the literature (Hooker, 1885; Pax \& Hoffmann, 1914) revealed that of 193 mentioned species 97 (about 50\%) are described to have EFNs on the leaf blade. This, however, is certainly an underestimation since many species had not been adequately described, and from almost a hundred species no data on this aspect were available.

Distribution of EFNs only partly reflects taxonomic relatedness within the genus Macaranga. Although there are some sections with prevalence of EFNs and its absence in others (Pseudo-Rottlera, Favanicae; Pachystemon sensu stricto, Winklerianae respectively), some sections comprise species with and without EFNs (Pachystemon sensu lato, M. pruinosa group, Stachyella). The taxonomic relationships of six species which have EFNs are unknown. One pattern, however, exists: all sections with a high percentage of myrmecophytic species have only a few or no species with additional EFNs on the lamina, whereas sections with high percentage of EFNs on the leaf surface do not contain myrmecophytes. Thus possession of EFNs does not appear to have been essential in the development of symbiotic ant-plant interactions. Myrmecophytes have evolved in taxa that lack EFNs, e.g. the Crypteroniaceae (Maschwitz et al., 1991) and papilionid myrmecophytes (McKey, 1989), whereas from Mimosiodeae in which EFNs are widespread only two myrmecophytes are known. In Macaranga, a genus in which $50 \%$ of the species worldwide carry EFNs, only about 15-20 species at most (less than $10 \%$ ) are thought be obligate myrmecophytes.

Of the other euphorb genera treated in this study only Endospermum contains myrmecophytes. None of the five myrmecophytic Endospermum of the total of 13 species worldwide occurs in Malaysia; the only Malaysian species is not inhabited by ants. All Endospermum species, however, possess glands. The other euphorb genera studied contain no myrmecophytes, but frequently develop glands: Mallotus in Malaysia has at least $52 \%$ of species with EFNs. Most species of Croton worldwide have EFNs (Bernhard, 1966), about $80 \%$ of the Croton species in West Malaysia are found with these glands and three of the four Malaysian Sapium spp. In West Malaysia at least 17 of 69 euphorb genera are known to have EFNs (unpublished work).

The effectiveness of the attraction to ants is usually enhanced when food bodies which ensure a more complete food for the ants are offered in addition to 
EFNs. Production of food bodies is a common feature in Macaranga (Fiala, 1988). Thus food availability for potential ant-partners does not appear to be a limiting factor in the evolution of close associations with ants. However, food body production appears to be more closely associated with development of obligate relationships between ants and Macaranga plants (Fiala \& Maschwitz, in press). We believe that predispositions other than EFNs have played a dominant role in the evolution of myrmecophytes in the genus Macaranga. Protodomatia (precursors of nesting space) seem to be the important feature, an opinion which has been supported by investigations of McKey (1989) in legume myrmecophytes. These other possible predispositions for Macaranga will be treated in detail in a future paper.

\section{ACKNOWLEDGEMENTS}

The director of the Forest Research Institute Malaysia (FRIM) Dato Dr Salleh Mohd Nor generously gave permission to work at FRIM and its field stations. We thank Mr K. M. Kochummen and Mr L. G. Saw for their support at the herbarium of FRIM. The Department of Zoology, Universiti Malaya granted permission to use their field station in Ulu Gombak. We are indebted to Wulf Killmann (GTZ) for logistic support. Sincere thanks go to Dr Jack Longino who kindly took on the task of identifying Crematogaster specimens. Manfred Ruppel helped with the SEM studies. This study was financially supported by the Deutsche Forschungsgemeinschaft and by research grants of the DAAD (German Academic Exchange Service) to B.F.

\section{REFERENCES}

BEATTIE, A. J., 1985. The Evolutionary Ecology of Ant-plant Mutualisms. Cambridge: Cambridge University Press.

BECERRA, J. X. \& VENABLE, D. L., 1989. Extrafloral nectaries: a defense against ant-homoptera mutualisms? Oikos, 55: 276-280.

BENTLEY, B. L., 1977. Extrafloral nectaries and protection by pugnacious bodyguards. Annual Review of Ecology and Systematics, 8: 407-427.

BERNHARD, F., 1966. Contribution à l'étude des glandes foliaires chez les Crotonoïdées (Euphorbiacées). Mémoires de l'Institut Fondamental d'Afrique Noire, 75: 71-156.

BRIAN, M. V., 1977. Ants. London: Collins.

BUCKLEY, R. C. (Ed.), 1982. Ant-plant Interactions in Australia. The Hague: W. Junk Publishers.

ELIAS, T. S., 1983. Extrafloral nectaries: their structure and distribution. In B. L. Bentley \& T. S. Elias (Eds), The Biology of Nectaries: 174-203. New York: Columbia Press.

ELIAS, T. S. \& GELBAND, H., 1977. Morphology, anatomy and relationship of extrafloral nectaries and hydathodes in two species of Impatiens. Botanical Gazette, 138: 206-212.

ESAU, K., 1969. Pflanzenanatomie. Stuttgart: Fischer.

FIALA, B., 1988. Biologie, Funktion und Evolution eines malaysischen Myrmekophytiesystems: Die Assoziation von Crematogaster borneensis (Form.: Myrmicinae) mit Bäumen der Gattung Macaranga (Euphorbiaceae). Unpublished $\mathrm{Ph}$. D. Thesis, University of Frankfurt.

FIALA, B., 1990. Extrafloral nectaries versus ant-Homoptera mutualisms: a comment on Becerra and Venable. Oikos, 59: 281-282.

FIALA, B. \& MASCHWITZ, U., 1990. Studies on the South East Asian ant-plant association Crematogaster borneensis/Macaranga: Adaptations of the ant partner. Insectes Sociaux, 37: 212-231.

FIALA, B., MASCHWITZ, U. \& THO, Y. P., 1991. The association between Macaranga and ants in South East Asia. In C. Huxley \& R. Cutler (Eds), Interactions between Ants and Plants: 263-270. Oxford: Oxford University Press.

FIALA, B., MASCHWITZ, U., THO, Y. P. \& HELBIG, A. J., 1989. Studies of a South East Asian ant-plant association: protection of Macaranga trees by Crematogaster borneensis. Oecologia, 79: 463-470.

FIALA, B. \& MASCHWITZ, U., in press. Food bodies in the genus Macaranga and their significance for the evolution of myrmecophytism. Botanical Journal of the Linnean Society. 
FRY-WYSSLING, A., 1935. Die Stoffausscheidung der höheren Pflanzen. Berlin: Springer.

HOOKER, J. D., 1885. The Flora of British India. Vol. 5. Ashford, Kent: Reeve \& Co.

HUXLEY, C. R., 1986. Evolution of benevolent ant-plant relationships. In B. Juniper \& R. Southwood (Eds), Insects and the Plant Surface: 257-282.

JANZEN, D. H., 1966. Coevolution of mutualism between ants and acacias in Central America. Evolution, 20: 249-275.

KEELER, K. H., 1989. Ant-plant interactions. In W. G. Abrahamson (Ed.), Plant-Animal Interactions: $207-242$. New York: MacGraw-Hill.

KOYAMA, H., 1978. Photosynthesis studies in Pasoh forest. Malayan Nature Fournal, 30: 253-278.

MACKAY, D. A. \& WHALEN, M. A., 1991. Some associations between ants and euphorbs in the Australasian tropics. In R. Cutler \& C. Huxley (Eds), Interactions between Ants and Plants: 238-249. Oxford: Oxford University Press.

MASCHWITZ, U., FIALA, B., MOOG, J. \& SAW, L. G., 1991. Two new myrmecophytic associations from the Malay Peninsula: ants of the genus Cladomyrma (Formicidae, Camponotinae) as partners of Saraca thaipingensis (Caesalpiniaceae) and Crypteronia griffthii (Crypteroniaceae). Insectes Sociaux, 38: 27-35.

McKEY, D., 1988. Promising new directions in the study of ant-plant mutualisms. In W. Greuter \& B. Zimmer (Eds), Proceedings of the XIV International Botanical Congress. Koenigstein (Germany): Koeltz Publishers.

McKEY, D., 1989. Interactions between ants and leguminous plants. In C. H. Stirton \& J. L. Zarucchi (Eds), Advances in Legume Biology. Monographs in Systematic Botany. St. Louis: Missouri Botanical Gardens.

MOKRASCH, L. C., 1954. Analysis of hexose phosphates and sugars with the anthrone reagent. Fournal of Biological Chemistry, 208: 55-59.

O'DOWD, D. J., 1979. Foliar nectar production and ant activity on a neotropical tree, Ochroma pyramidale. Oecologia (Berlin), 43: 233-248.

PAX, F. \& HOFFMANN, K., 1914. Euphorbiaceae. In A. Engler, Das Pflanzenreich, 63. Heft. Leipzig: W. Engelmann.

SCHNELL, R., CUSSET, G. \& QUENUM, M., 1963. Contribution à l'étude des glandes extraflorales chez quelques groupes des plantes tropicales. Revue Générale de Botanique, 70: 269-342.

SCHUPP, E. W. \& FEENER, D. H., 1991. Phylogeny, lifeform and habitat dependence of ant-defended plants in a Panamanian forest. In R. Cutler \& C. Huxley (Eds), Interactions between Ants and Plants: 175-197. Oxford: Oxford University Press.

WHALEN, M. A. \& MACKAY, D. A., 1988. Patterns of ant and herbivore activity on five understory euphorbiaceous saplings in submontane Papua New Guinea. Biotropica, 20(4): 294-300.

WHITMORE, T. C., 1967. Studies in Macaranga, an easy genus of Malayan wayside trees. Malayan Nature Journal, 20: 89-99.

WHITMORE, T. C., 1969. First thoughts on species evolution in Malayan Macaranga. Biological fournal of the Linnean Society, 1: 223-231.

WHITMORE, T. C., 1973. Tree Flora of Malaya. Kuala Lumpur, London: Longman.

WHITMORE, T. G., 1975. Macaranga. In H. K. Airy Shaw (Ed.), The Euphorbiaceae of Borneo. Kerw Bulletin Additional Series, 4: 140-159.

WHITMORE, T. C., 1979a. Studies in Macaranga, X. Potentially commercial species in New Guinea. Commonwealth Forestry Review, 58(4): 271-272.

WHITMORE, T. C., 1979b. Macaranga in New Guinea and the Bismarck Archipelago. Kew Bulletin, 34: 599-606.

WILSON, E. O., 1971. The Insect Societies. Cambridge, Massachusetts: Belknap Press. 
